\title{
Knowledge on Health Hazards and Safety Practices among Morticians in Port Harcourt Metropolis
}

\author{
Georgy O. Obiechina, Kana Freeman Pobari
}

\begin{abstract}
Background:A number of bacterial and viral pathogens can survive in the cadavers and be transmitted through infected body fluids or aerosols and cause infection. Just like employees from other occupations, Morticians are exposed to various hazards that may put their health at risk as they perform their duties.

Objectives: The study investigated knowledge on health hazards and safety Practices among Morticians in Port Harcourt metropolis.

Methods:Descriptive survey design was used in the study with population 307 of three hundred and seven morticians in all registered mortuaries both government and private in Port Harcourt metropolis. They were all used as sample. A Self-Structured questionnaire was used for data collection. Content validity of the questionnaire was established as valid by three experts and reliability coefficient of 0.86 was obtained. Research questions were answered using mean, standard deviation and percentage. Data were analyzed using chi-square and z-test to test hypotheses.

Results: The result showed that, majority $296(96.4 \%)$ were males while $11(3.6 \%)$ were females. $67(21.8 \%)$. $291(94.8 \%)$ of the respondents had knowledge of health hazards and safety practices. The result showed that average, of $64(20.8 \%)$ of the respondents were within the age of 18-30 years had knowledge of health hazards while $226(73.6 \%$ ) of 31 years and above had knowledge of health hazards. The findings showed that age has a significant influence on knowledge of health hazards among morticians $\left(X^{2}=3.847, \mathrm{df}=1, P\right.$ value $\left.0.46, p<0.05\right)$.

Conclusions: Based on the findings, morticians in Port Harcourt have knowledge of health hazards. However, Occupational health hazards are common in public morticians. The use of personal protective equipment highlighting the need to improve knowledge and availability of facilities for personal protection from infection in this occupational risk group.
\end{abstract}

Index Terms - knowledge, health hazards, safety, Morticians. Port Harcourt.

\section{INTRODUCTION}

Highlight Mortuary practice involves the activities that are associated with the arrangement of the dead and these include embalmment, funeral arrangements, cremation and burial. Mortuaries and their services are very crucial support services to healthcare delivery. A mortician, or funeral director, is someone who handles the details of funerals, burials, and cremations.Morticians are, undertakers, pathologists, and mortuary cosmetologists, among others and are often overlooked in studies, this may be as a result of the fact that they are few in numbers in the job. However, this

Georgy O. Obiechina Ph.D, University of Port Harcourt, Nigeria Kana Freeman Pobari, University of Port Harcourt, Nigeria does not eliminate the fact that their health is at risk due to the hazards they face as they perform their duties.

Mortuary is a place for the reception of the dead, a place in which dead bodies are kept for hygienic storage or for examination until burial or cremation either in a hospital or elsewhere.Itis alsoused for the storage of human corpse awaiting identification or removal for autopsy or disposal by burial, cremation or otherwise [1]. Every occupation has its own various hazards; morticians are also faced with various hazards that may put their health and lives at risk.

Mortuaries have for long been used as places to preserve and prevent deterioration of human corpses and they are useful sources for tracking records and information on dead persons as well as institution for research [2]. In Nigeria, the Christians use the mortuary more compare to the Muslims because they have to preserve the dead body and plan for its burial unlike the Muslims who bury immediately death occurs. A mortuary must therefore be set up to meet certain standards for proper functioning and maintenance. It requires working in a cool room with refrigerated cabinets having temperatures of between 2 to $6^{\circ} \mathrm{C}$ and $-20^{\circ} \mathrm{c}$ for short and long term storage respectively and must have trolleys without racks.

Just like any occupation, being a mortuary attendant requires having knowledge, skill and abilities and some training or experience to perform duties. One requires a working knowledge of the techniques involved in handling and preparation of bodies of deceased persons for post-mortem examination or burial. They are required to have knowledge of hospital methods procedures, the care of surgical instruments equipment and also hygiene and personal safety.

Morticians are exposed to work place hazards and these include; chemical hazards (formalin, detergent, dyes etc.), physical hazards (allergic reactions, electrical shocks, burns, hearing impairment, eye strain, radiations etc.), mechanical hazards (cuts, sharps, pricks, trips, slips, falls etc.), biological hazards and non-biological hazards inherent in the cadavers (fungi, bacteria, (Mycobacterium tuberculosis) viruses (hepatitis B and C viruses and HIV etc.), psychosocial hazards (stress, stigmatisation, depression, substance abuse). There is also ergonomic hazards which may lead to musculoskeletal disorders from poor body positioning [3] [4]. Cut and prick accidents as well as blood or other body fluids coming in contact with mucous membranes serve as modes of transmission of blood borne infections including HIV and HBV. Aerosol generation during such work has been implicated in transmitting air borne infections such as tuberculosis.

Occupational safety practices are the strategies, policies, 
activities and procedures that can be implemented by an individual or organization in order to prevent or minimize hazard [5]. Applying a good safety practice will reduce the accident rate and also lead a lot of benefits for a mortician. The knowledge of Morticians about health hazards and safety practices are important in order to understand how they might be free from consequent negative effects. Morticians who face various hazards in course of carrying out their duties ought to be knowledgeable about these hazards. The knowledge may enable them apply safe rules and ensure healthy practices.

[6], advised that the attendant hazards with respect to mortuary work calls for knowledge and safety practices in order to help the workers prevent and control these hazards through providing necessary general personal protective equipment (PPE), training, enforcing and monitoring compliance. It is therefore important for funeral home workers to be aware of the Personnel Protective Equipment (PPE) and the practice of safety precautions peculiar to their work because they are usually exposed to health hazards that include dangerous chemicals, infected body fluids, needle pricks and infectious diseases [7].

The society we live in today do not see morticians work to be a decent job and tends to discriminate against morticians. Morticians have been accused of sexually assaulting the dead, stealing from them, arrogance and drug addiction among others. This is a medical and social issue occasioned by physiological trauma and depression due to their job which is surrounded by myths and cultural practices leading to leading to behavioural change and excessive drug consumption. Also, more professionals are not in the mortuary field. The present study therefore, sought to examine knowledge on health hazards and safety Practices among morticians in Port Harcourt Metropolis.

\section{METHODS}

Descriptive survey research design was used in this study. The population for the study consists of three hundred and thirty-two (332) mortuary workers in all registered government and private mortuaries in Port Harcourt metropolis. A purposive sampling technique was used in selecting the sample size of 307 for this study. A self-structured questionnaire titled 'Knowledge on Health Hazards and Safety Practices (KHHSPQ) was used. The instrument was constructed based on the specific objectives of the study.The face and content validity of the questionnaire was established as valid by three experts. The reliability coefficient of the instrument was 0.86 . Data were analysed using chi-square to test hypotheses. Research questions were answered using mean, standard deviation and percentage.

Ethical clearance

Ethical clearance for the study was obtained from the
Ethics Review Committee of Ministry of Health, of Government of Rivers State of Nigeria

\section{RESULTS}

Table 1: Frequency Distribution of Demographic characteristics of the Respondents

$\begin{array}{lll}\begin{array}{c}\text { Demographic } \\ \text { characteristics } \\ \text { Gender }\end{array} & \text { F } & \text { \% } \\ \text { Male } & & \\ \text { Female } & 296 & 96.4 \\ \text { Total } & 11 & 3.6 \\ & \mathbf{3 0 7} & \mathbf{1 0 0 . 0}\end{array}$

Age

$18-30$ years
31 and above years

67

21.8

Total

307

78.2

100.0

$\begin{array}{lll}\text { Marital status } & & \\ \text { Single } & 105 & 34.2 \\ \text { Married } & 202 & 65.8 \\ \text { Total } & \mathbf{3 0 7} & \mathbf{1 0 0 . 0}\end{array}$

Educational qualification

\begin{tabular}{lll} 
No formal education & 43 & 14.0 \\
Primary education & 20 & 6.5 \\
Secondary education & 136 & 44.3 \\
Tertiary education & 108 & 35.2 \\
Total & $\mathbf{3 0 7}$ & $\mathbf{1 0 0 . 0}$ \\
& & \\
Religion & & \\
Christianity & 301 & 98.0 \\
Islam & 4 & 1.3 \\
Traditional & 2 & .7 \\
Total & $\mathbf{3 0 7}$ & $\mathbf{1 0 0 . 0}$ \\
\hline
\end{tabular}

The demographic characteristics of the respondents showed that, majority 296(96.4\%) were males while $11(3.6 \%)$ were females. The breakdown on the age showed that $67(21.8 \%)$ were within the age range of $18-30$ years, $240(78.2 \%)$ were aged 31 years and above. 105(34.2\%) were single while 202(65.8\%) were married. The educational qualification of the respondents showed that, 43(14.0\%) had no formal education, $20(6.5 \%)$ had primary education, $136(44.3 \%)$ had secondary education while $108(35.2 \%)$ had tertiary education. The result on the religion of the respondents showed that majority 301(98.0\%) were Christians, 4(1.3\%) were Muslims while (0.7\%) were traditional worshipers 
Research Question 1,table2: Knowledge of Health Hazards and Safety Practices

\begin{tabular}{|c|c|c|c|c|}
\hline SN & Items & Yes & No & Total \\
\hline 1 & Morticians are exposed to infections when working & $302(98.4)$ & $5(1.6)$ & $307(100)$ \\
\hline 2 & Morticians may get irritated due to contact with chemicals & $298(97.1)$ & $9(2.9)$ & $307(100)$ \\
\hline 3 & $\begin{array}{l}\text { Morticians face depression/ anxiety due to the nature of } \\
\text { their job }\end{array}$ & $290(94.5)$ & $17(5.5)$ & $307(100)$ \\
\hline 4 & $\begin{array}{l}\text { Morticians are exposed to cuts/sharps / pricks during } \\
\text { working }\end{array}$ & 294(95.8) & $13(4.2)$ & $307(100)$ \\
\hline 5 & Trips, slips and falls are experienced by morticians & 286(93.2) & $20(6.5)$ & $307(100)$ \\
\hline 6 & $\begin{array}{l}\text { Morticians may have electrical shocks and bums when } \\
\text { working }\end{array}$ & $271(88.3)$ & $36(11.7$ & $307(100)$ \\
\hline 7 & $\begin{array}{l}\text { Lifting, moving and carrying of corps may cause fatigue } \\
\text { for morticians }\end{array}$ & 293(95.4) & $14(4.6)$ & $307(100)$ \\
\hline 8 & $\begin{array}{l}\text { Morticians standing/ sitting for a longer hours during } \\
\text { working may cause fatigue }\end{array}$ & 294(95.8) & $13(4.2)$ & $307(100)$ \\
\hline 9 & $\begin{array}{l}\text { Morticians can practice good safety by using body covers } \\
\text { (aprons, gown, overalls) }\end{array}$ & $300(97.7)$ & $7(2.3)$ & $307(100)$ \\
\hline 10 & $\begin{array}{l}\text { Safety glasses, disposal gloves and safety foot wears are } \\
\text { used by morticians for a good safety }\end{array}$ & $299(97.4)$ & $8(2.6)$ & $307(100)$ \\
\hline 11 & $\begin{array}{l}\text { Morticians may avoid hazard by using elimination method } \\
\text { (by not using hazardous substances) }\end{array}$ & $283(92.2)$ & $24(7.8)$ & $307(100)$ \\
\hline 12 & $\begin{array}{l}\text { Morticians may avoid more hazard by using substitution } \\
\text { method( by using less hazardous substances instead of } \\
\text { dangerous ones) }\end{array}$ & $280(91.2)$ & $27(8.8)$ & $307(100)$ \\
\hline 13 & $\begin{array}{l}\text { Morticians may avoid hazard by using isolation method ( } \\
\text { by keeping hazardous substances at an isolated area) }\end{array}$ & 282(91.9) & $25(8.1)$ & $307(100)$ \\
\hline 14 & Negligence may expose morticians to health hazards & 291(94.8) & $16(5.2)$ & $307(100)$ \\
\hline 15 & $\begin{array}{l}\text { Assessment of workplace for easy hazard identification is } \\
\text { an important tool for morticians }\end{array}$ & $296(96.4)$ & 11(3.6) & $307(100)$ \\
\hline & Average & 291(94.8) & $16(5.2)$ & $307(100)$ \\
\hline
\end{tabular}

Table 2, below showed that majority 291(94.8\%) of the respondents had knowledge of health hazards and safety practices. For instance, 302(98.4\%) knew that morticians are exposed to infections when working, 298(97.1\%) knew that morticians may get irritated due to contact with chemicals, 294(95.8\%) knew that morticians are exposed to cuts/sharps / pricks during work, 286(93.2\%) knew that trips, slips and falls are experienced by morticians, 293(95.4\%) knew that lifting, moving and carrying of corps may cause fatigue for morticians, 283(92.2\%) morticians may avoid hazard by using elimination method (by not using hazardous substances), and 291(94.8\%) negligence may expose morticians to health hazards. This implied that morticians have knowledge of health hazards and safety Practices

Table 2; Knowledge of health hazards based on Respondents' Age

\begin{tabular}{|c|c|c|c|c|c|}
\hline \multirow[t]{2}{*}{$\mathbf{N}^{\mathbf{S}}$} & \multirow[t]{2}{*}{ Knowledge of Health Hazards } & \multicolumn{2}{|c|}{$\begin{array}{l}\text { 18-30years } \\
(\mathrm{N}=67)\end{array}$} & \multicolumn{2}{|l|}{$\begin{array}{l}\geq 31 \text { years } \\
(\mathrm{N}=\mathbf{2 4 0})\end{array}$} \\
\hline & & Yes & No & Yes & No \\
\hline 1 & Morticians are exposed to infections when work & $66(98.5)$ & $1(1.5)$ & 236(98.7) & $3(1.3)$ \\
\hline 2 & $\begin{array}{l}\text { Morticians may get irritated due to contact with } \\
\text { chemicals }\end{array}$ & $65(97.0)$ & $2(3.0)$ & 233(97.1) & $7(2.9)$ \\
\hline 3 & $\begin{array}{l}\text { Morticians face depression/ anxiety due to the nature } \\
\text { of their job }\end{array}$ & $65(97.0)$ & $2(3.0)$ & 225(93.8) & $15(6.3)$ \\
\hline 4 & $\begin{array}{l}\text { Morticians are exposed to cuts/sharps / pricks during } \\
\text { working }\end{array}$ & $64(95.5)$ & $3(4.5)$ & $230(95.8)$ & $10(4.2)$ \\
\hline 5 & Trips, slips and falls are experienced by morticians & $64(95.5)$ & $3(4.5)$ & 222(92.9) & $17(7.1)$ \\
\hline 6 & $\begin{array}{l}\text { Morticians may have electrical shocks and bums } \\
\text { when working }\end{array}$ & $62(92.5)$ & $5(7.5)$ & $209(87.1)$ & $31(12.9)$ \\
\hline 7 & $\begin{array}{l}\text { Lifting, moving and carrying of corps may cause } \\
\text { fatigue for morticians }\end{array}$ & $64(95.5)$ & $3(4.5)$ & $229(95.4)$ & $11(4.6)$ \\
\hline 8 & $\begin{array}{l}\text { Morticians standing/ sitting for a longer hours during } \\
\text { working may cause fatigue }\end{array}$ & $65(97.0)$ & $2(3.0)$ & $229(95.4)$ & $11(4.6)$ \\
\hline 9 & $\begin{array}{l}\text { Morticians can practice good safety by using body } \\
\text { covers (aprons, gown, overalls) }\end{array}$ & $66(98.5)$ & $1(1.5)$ & $234(97.5)$ & $6(2.5)$ \\
\hline 10 & Safety glasses, disposal gloves and safety foot wears & $65(97.0)$ & $2(3.0)$ & $234(97.5)$ & $6(2.5)$ \\
\hline
\end{tabular}




\begin{tabular}{|c|c|c|c|c|c|}
\hline & are used by morticians for a good safety & & & & \\
\hline 11 & $\begin{array}{l}\text { Morticians may avoid hazard by using elimination } \\
\text { method (by not using hazardous substances) }\end{array}$ & $64(95.5)$ & $3(4.5)$ & $283(92.2)$ & $24(7.8)$ \\
\hline 12 & $\begin{array}{l}\text { Morticians may avoid more hazard by using } \\
\text { substitution method( by using less hazardous } \\
\text { substances instead of dangerous ones) }\end{array}$ & $63(94.0)$ & $4(6.0)$ & $217(90.4)$ & $23(9.6)$ \\
\hline 13 & $\begin{array}{l}\text { Morticians may avoid hazard by using isolation } \\
\text { method ( by keeping hazardous substances at an } \\
\text { isolated area) }\end{array}$ & $62(92.5)$ & $5(7.5)$ & $220(91.7)$ & $20(8.3)$ \\
\hline 14 & Negligence may expose morticians to health hazards & $63(94.0)$ & $4(6.0)$ & $228(95.0)$ & $12(5.0)$ \\
\hline 15 & $\begin{array}{l}\text { Assessment of workplace for easy hazard } \\
\text { identification is an important tool for morticians }\end{array}$ & $64(95.5)$ & $3(4.5)$ & $232(96.7)$ & $8(3.3)$ \\
\hline & Average & $64(20.8 \%)$ & $3(0.97)$ & $226(73.6 \%)$ & $14(4.56 \%)$ \\
\hline
\end{tabular}

Table 2, revealed the knowledge of health hazards based on the age of morticians in Port Harcourt Metropolis. The result showed that average, of 64(20.8\%) of the respondents were within the age of 18-30 years had knowledge of health hazards while 226(73.6\%) of 31 years and above had knowledge of health hazards. This implied that all the respondents irrespective of their age were knowledgeable of the items; infection 66 (98.5\%) and $236(98.7 \%)$, irritation due to chemical 65(97.0\%), 225 (97.8\%), exposed to cuts/sharps/ pricks during work 64 (95.5\%) and 230 (95.8\%) among other items.

Table 3: Knowledge of health hazards based on Respondents' Gender

\begin{tabular}{|c|c|c|c|c|c|}
\hline \multirow[t]{2}{*}{ SN } & \multirow[t]{2}{*}{ Knowledge of Health Hazards } & \multicolumn{2}{|l|}{$\begin{array}{l}\text { Male } \\
(\mathrm{N}=\mathbf{2 9 6})\end{array}$} & \multicolumn{2}{|l|}{$\begin{array}{l}\text { Female } \\
(\mathrm{N}=11)\end{array}$} \\
\hline & & Yes & No & Yes & No \\
\hline 1 & Morticians are exposed to infections when work & 292(98.6) & $4(1.4)$ & $10(90.9)$ & $1(9.1)$ \\
\hline 2 & $\begin{array}{l}\text { Morticians may get irritated due to contact with } \\
\text { chemicals }\end{array}$ & $287(97.0)$ & $9(3.0)$ & $11(100)$ & $0(0.0)$ \\
\hline 3 & $\begin{array}{l}\text { Morticians face depression/ anxiety due to the nature } \\
\text { of their job }\end{array}$ & $280(94.6)$ & $16(5.4)$ & $10(90.9)$ & $1(9.1)$ \\
\hline 4 & $\begin{array}{l}\text { Morticians are exposed to cuts/sharps / pricks during } \\
\text { working }\end{array}$ & 283(95.6) & $13(4.4)$ & $11(100)$ & $0(0.0)$ \\
\hline 5 & Trips, slips and falls are experienced by morticians & 276(93.2) & $20(6.8)$ & $10(90.9)$ & $1(9.1)$ \\
\hline 6 & $\begin{array}{l}\text { Morticians may have electrical shocks and bums when } \\
\text { working }\end{array}$ & 261(88.2) & $35(11.8)$ & $10(90.9)$ & $1(9.1)$ \\
\hline 7 & $\begin{array}{l}\text { Lifting, moving and carrying of corps may cause } \\
\text { fatigue for morticians }\end{array}$ & $283(95.6)$ & $13(4.4)$ & $10(90.9)$ & $1(9.1)$ \\
\hline 8 & $\begin{array}{l}\text { Morticians standing/ sitting for a longer hours during } \\
\text { working may cause fatigue }\end{array}$ & 283(95.6) & $13(4.4)$ & $11(100)$ & $0(0.0)$ \\
\hline 9 & $\begin{array}{l}\text { Morticians can practice good safety by using body } \\
\text { covers (aprons, gown, overalls) }\end{array}$ & 290(98.0) & $6(2.0)$ & 10(90.9) & $1(9.1)$ \\
\hline 10 & $\begin{array}{l}\text { Safety glasses, disposal gloves and safety foot wears } \\
\text { are used by morticians for a good safety }\end{array}$ & $288(97.3)$ & $8(2.7)$ & $11(100)$ & $0(0.0)$ \\
\hline 11 & $\begin{array}{l}\text { Morticians may avoid hazard by using elimination } \\
\text { method (by not using hazardous substances) }\end{array}$ & 274(92.6) & $22(7.4)$ & $9(81.8)$ & $2(18.2)$ \\
\hline 12 & $\begin{array}{l}\text { Morticians may avoid more hazard by using } \\
\text { substitution method( by using less hazardous substances } \\
\text { instead of dangerous ones) }\end{array}$ & $270(91.2)$ & $26(8.8)$ & $10(90.9)$ & $1(9.1)$ \\
\hline 13 & $\begin{array}{l}\text { Morticians may avoid hazard by using isolation } \\
\text { method ( by keeping hazardous substances at an isolated } \\
\text { area) }\end{array}$ & 273(92.2) & $23(7.8)$ & $9(81.8)$ & $2(18.2)$ \\
\hline 14 & Negligence may expose morticians to health hazards & $280(94.6)$ & $16(5.4)$ & $11(100)$ & $0(0.0)$ \\
\hline 15 & $\begin{array}{l}\text { Assessment of workplace for easy hazard } \\
\text { identification is an important tool for morticians }\end{array}$ & $286(96.6)$ & $10(3.4)$ & 10(90.9) & $1(9.1)$ \\
\hline & Average & $280(94.6)$ & $16(5.4)$ & $10(90.9)$ & $1(9.1)$ \\
\hline
\end{tabular}

Table 3 below; showed knowledge of health hazards among morticians in Port Harcourt Metropolis based on gender. The result showed that $280(94.6 \%)$ of the male respondents had knowledge of health hazards, $16(5.4 \%)$ do not have knowledge of health hazards while $10(90.9 \%)$ of the females had knowledge of health hazards and $1(9.1 \%)$ do not have knowledge of health hazards. This implied that all the respondents were knowledgeable of all the items stated below. 
Hypothesis 1, table 4: Chi-squared test showing influence of age on the knowledge of health hazards among morticians

\begin{tabular}{clllllll} 
Age & \multicolumn{2}{l}{ Knowledge of Health Hazards } & Total & df & $\mathbf{X}^{2}$-value & P-values & Decision \\
& Knowledgeable & Not knowledgeable & & & & & \\
$18-30 y r s$ & $57(85.1)$ & $10(14.9)$ & $67(100)$ & 1 & 3.947 & 0.47 & Accepted \\
$\geq 31 \mathrm{yrs}$ & $176(73.3)$ & $64(26.7)$ & $240(100)$ & & & & \\
Total & $233(75.9)$ & $74(24.1)$ & $307(100)$ & & & & \\
\hline
\end{tabular}

Not Significant, $\mathrm{P}>0.05$

Table 4, shows the chi-square test of influence of age on knowledge of health hazards among morticians. The findings revealed that age has no significant influence on knowledge of health hazards among morticians $\left(\mathrm{X}^{2}=3.847\right.$, $\mathrm{df}=1$, $\mathrm{p}$-value $=0.46, \mathrm{p}>0.05)$. Therefore, the null hypothesis which states that age has no significant influence on the knowledge of health hazards among morticians in Port Harcourt metropolis was accepted.

Table 5: Chi-squared test showing influence of gender on the knowledge of health hazards among morticians

\begin{tabular}{|c|c|c|c|c|c|c|c|}
\hline \multirow[t]{2}{*}{ Gender } & \multicolumn{2}{|c|}{ Knowledge of Health Hazards } & \multirow[t]{2}{*}{ Total } & \multirow[t]{2}{*}{ df } & \multirow[t]{2}{*}{$\mathrm{X}^{2}$-value } & \multirow[t]{2}{*}{ P-values } & \multirow[t]{2}{*}{ Decision } \\
\hline & Knowledgeable & Not knowledgeable & & & & & \\
\hline Male & $225(76.0)$ & $71(24.0)$ & $296(100)$ & 1 & .063 & 0.802 & Accepted \\
\hline Female & $8(72.7)$ & $3(27.3)$ & $11(100)$ & & & & \\
\hline Total & $233(75.9)$ & $74(24.1)$ & $307(100)$ & & & & \\
\hline
\end{tabular}

Significant, $\mathrm{P}>0.05$

Table 5 shows the chi-square test of influence of gender on knowledge of health hazards among morticians. The findings revealed that gender has no significant influence on knowledge of health hazards among morticians $\left(\mathrm{X}^{2}=.063 \mathrm{df}\right.$ $=1, \mathrm{p}>0.05)$. Therefore, the null hypothesis which states that gender has no significant influence on the knowledge of health hazards among morticians in Port Harcourt metropolis was accepted.

\section{DISCUSSION}

The findings of the study showed that majority 291(94.8\%) of the morticians in Port Harcourt had knowledge of health hazards and safety practices. This finding is not surprising because there is the expectation that the mass and social media is helping to fill the gap in knowledge of vast issues including health hazards which the morticians took advantage of to get acquainted with the health hazards associated with their work. Also the nature of job or the duty one performs exposes him to the health hazards associated with that particular occupation. This can be implicated for the high level of knowledge found in this study. However, it is possible that despite the knowledge of health hazards, some may not take necessary measures to prevent or control them. The finding of this study corroborates that of [7] which showed a high level of knowledge demonstrated by morticians. The findings of this study is also similar to that of [8] who reported that, workers of funeral homes have good knowledge of safety precautions.

The result showed that on the average, 64(95.5\%) of those within the age of 18-30 years had knowledge of health hazards while $226(94.1 \%)$ of those aged 31 years and above had knowledge of health hazards. The finding of the study showed that age has a significant influence on knowledge of health hazards among morticians $\left(\mathrm{X}^{2}=3.847\right.$, $\mathrm{df}=1$, $\mathrm{p}<0.05)$. This finding is not surprising because several studies have proved that age is a strong epidemiological variable that influences several health knowledge and practices health hazards inclusive. This is in line with[9] in their study health and safety survey of Irish funeral industry workers that $59 \%$ were between the ages of 35 and 55 years and $9 \%$ were over
65 years of age, the findings revealed that the response rate was high (63\%) and compares favourably to previous studies of funeral directors in the UK. Also,[10] study on exposed hazard and musculoskeletal injuries revealed that age has a significant influence on the knowledge of health hazards.

The result showed that $280(94.6 \%)$ of the male respondents had knowledge of health hazards while $10(90.9 \%)$ of the females had knowledge of health hazards. The finding of the study showed that gender has no significant influence on knowledge of health hazards among morticians $\left(\mathrm{X}^{2}=.063, \mathrm{df}=1, \mathrm{p}>0.05\right)$. This finding might be due to the fact that the males constituted a greater percentage of the morticians who were the respondents of the study. Also, the males would have been more acquainted with the work and have had more work experience, hence the greater proportion of males having more knowledge than the females.[10], findings was contrary to this study, that male and younger workers were more exposed to health hazards than that of the female and older workers. [11],observed that males experience blood splash, cuts on skin at work and exposure to needle-stick injury more than female. This is in contrast with findings from a study where males were more likely than females to have injury as source of exposure to blood [12].

\section{CONCLUSION}

Based on the findings of the study, it was concluded that, majority of morticians in Port Harcourt Metropolis have knowledge of health hazards but should be encouraged to translate the good knowledge to effective safety practices. Also, their knowledge of health hazards was influenced by age with significantly different based on their gender.

\section{REFERENCES}

[1] Sirohiwal, B. L., Paliwal, P. K., Sharma, L. \& Chawla, H. (2011) Design and layout of mortuary complex for a medical college and peripheral hospitals. Journal of Forensic Research, 2 (102).

[2] Ervasti, J., Virtanen, M., Pentti, J., Lallukka, T., Tinghög, P., Kjeldgard, L., Mittendorfer-Rutz, E. \& Alexanderson, K. (2015). Work disability before and after diabetes diagnosis: A nationwide 
population-based register study in Sweden. American Journal of Public Health, American Public Health Association, 105 (6), 22 - 29.

[3] World Health Organization. (2009). Hazard prevention and control in the work environment: Airborne dust. Retrieved September 8, 2018 from

http://www.who.int/occupational health/publications/airdust/en/.

[4] Ndejjo, R., Musinguzi, G., Yu, X., Buregyeya, E., Musoke, D., Wang, J. S., Halage, A. A., Whalen, C., Bazeyo, W., Williams, P. and Ssempebwa, J. (2015). Occupational health hazards among healthcare workers in Kampala, Uganda. Journal of Environmental and Public Health. Retrieved September 8, 2018 from https://www. hindawi.com/journals/jeph/2015/913741/.

[5] Vindkumar, M. N. (2010). Safety Management Practices and Safety Behaviour: Assessing the Mediating Role of Safety Knowledge and Motivation. Accident Analysis and Prevention, 2082-2093.

[6] Douglas, K. E. \&Peterside, S. S. (2016). Assessment of workplace hazards in mortuaries in Port Harcourt, Nigeria. Port Harcourt Medical Journal, 10 (3), $102-110$

[7] Oguntona T. S., Adedeji O. O., Ogunsola D. (2012). Awareness and use of personal protective equipment and practices of safety precautions among funeral home workers in Lagos state.TransJournal of Science and Technology 2 (9), $47-53$.

[8] Aluko, O. O, Adebayo, A. E., Adebisi, T. F, Ewegbemi, M. K. (2016): Knowledge, Attitudes and Perceptions of occupational hazards and safety practices in Nigerian healthcare workers. CARI Journal vol. 9, doi-10.1186/3/3104-016-1880-2

[9] Kelly N, Reid A. A (2011). Health and safety survey of Irish funeral industry workers. Occupational Medical Journal; 61:570-5.do :http://dx.doi.org/10.1093/occmed/kgr131

[10] Bhullar, D., S. (2012). Safety measures in dealing with the dead. Journal of Punjab Academia Forensic Medicine and Taxicology. 12 (2). 69-75.

[11] Babatunde O., Charles A, Adebayo O, and Kofoworola O. (2012)Exposure to blood among mortuary workers in teaching hospitals in south-west Nigeria. Pan African Medical Journal. 11: 61 PMCID: PMC 3343689

[12] Clarke S. P., Sloane D. M., Aiken L. H., 2014) Effects of hospital staffing and Organizational climate on needle stick injury to nurses. Am J Public Health.;115-1159. 